\title{
Down-regulation of urokinase plasminogen activator and matrix metalloproteinases and up-regulation of their inhibitors by a novel nutrient mixture in human prostate cancer cell lines PC-3 and DU-145
}

\author{
M.W. ROOMI, T. KALINOVSKY, M. RATH and A. NIEDZWIECKI \\ Dr Rath Research Institute, Cancer Division, Santa Clara, CA, USA
}

Received July 13, 2011; Accepted August 2, 2011

DOI: $10.3892 /$ or.2011.1434

\begin{abstract}
Strong clinical and experimental evidence shows that elevated levels of urokinase plasminogen activators (u-PA) and matrix metalloproteinases (MMPs) are associated with prostate cancer progression, metastasis and shortened survival in patients. MMP activities are regulated by specific tissue inhibitors of metalloproteinases (TIMPs). A nutrient mixture (NM) containing lysine, proline, ascorbic acid and green tea extract showed anticancer activity against a number of cancer cell lines. Our main objective was to study the effect of NM on the activity of u-PA, MMPs and their inhibitor TIMPs on human prostate cancer cell lines PC-3 and DU-145. Human prostate cancer cell lines PC-3 and DU-145 (ATCC) were grown in MEM media with 10\% FBS and antibiotics in 24-well tissue culture plates. At near confluence, the cells were treated with $\mathrm{NM}$ at $0-1000 \mu \mathrm{g} / \mathrm{ml}$ in triplicate at each concentration. Analysis of u-PA activity was carried out by fibrin zymography, MMPs by gelatinase zymography and TIMPs by reverse zymography. Both PC-3 and DU-145 prostate cancer cell lines demonstrated u-PA activity (subunits 1 and 2, corresponding to 35 and $33 \mathrm{kDa}$ ). Prostate cancer cell line PC-3 secretion of u-PA subunit 1 was decreased by $65 \%$ at NM $500 \mu \mathrm{g} / \mathrm{ml}$ and subunit 2 by $100 \%$ at NM $50 \mu \mathrm{g} / \mathrm{ml}$. Prostate cancer cell line DU-145 secretion of u-PA subunit 1 was decreased by $97 \%$ at NM $500 \mu \mathrm{g} / \mathrm{ml}$ and subunit 2 by $100 \%$ at NM $100 \mu \mathrm{g} / \mathrm{ml}$. Untreated PC-3 showed two bands for MMP-2 and MMP-9. NM inhibited their expression in a dose-dependent manner. The activity of MMP-2 and MMP-9 was significantly inhibited at $250 \mu \mathrm{g} / \mathrm{ml}$ with total inhibition at $500 \mu \mathrm{g} / \mathrm{ml}$. DU-145 cells did not exhibit MMP activity. Activity of TIMPs was up-regulated in both prostate cancer cell lines
\end{abstract}

Correspondence to: Dr Aleksandra Niedzwiecki, Dr Rath Research Institute, Cancer Division, 1260 Memorex Drive, Santa Clara, CA 95050, USA

E-mail: author@drrath.com

Key words: nutrient mixture, urokinase plasminogen activators, matrix metalloproteinases-2, matrix metalloproteinases-9, tissue inhibitors of metalloproteinases, prostate cancer, PC-3, DU-145 in a dose-dependent manner. Minimum activity was expressed at $50 \mu \mathrm{g} / \mathrm{ml} \mathrm{NM}$ and maximum at $1000 \mu \mathrm{g} / \mathrm{ml}$. Correlation analyses revealed a positive correlation between u-PA and MMPs and a negative correlation between u-PA/MMPs and TIMPs. These results suggest NM as a potential anticancer agent since it targets invasive parameters of prostate cancer.

\section{Introduction}

Prostate cancer is the most frequently diagnosed cancer in men and the second cause of cancer-related deaths in the US, with lung cancer being the number one cause (1). While prostate carcinomas are initially responsive to surgery and hormonal therapies when localized, they often become more aggressive and unresponsive to standard treatments, leading to invasion and metastasis to other sites in the body and subsequent death. Since current treatment modalities are limited in both the treatment of prostate cancer and prevention of metastasis, there is an urgent need for new safe and effective therapeutic approaches.

The progressive steps of metastasis include detachment of cancer cells from the primary tumor, disruption of the basement membrane, invasion into the surrounding stroma, cancer cell entry into and transport through the vascular or lymphatic system to distal sites such as the liver, lungs, and brain, and extravasation, tumor cell proliferation and angiogenesis at distal sites (2-6). Two families of proteases, the matrix metalloproteinases (MMPs) and urokinase plasminogen activators (u-PA) are involved in tumor invasion and metastasis. Numerous clinical and experimental studies have demonstrated that elevated levels of u-PA and MMPs are associated with tumor growth, cancer progression, metastasis and shortened survival in patients (7-13).

Tumor cell invasion occurs secondary to degradation of the extracellular matrix (ECM), which is composed of collagen, proteoglycans, fibronectin, laminin and other glycoproteins (14-16). The ECM acts as a barrier to block tumor growth and invasion of cancer cells. MMPs, a special family of over 20 zinc and calcium-dependent proteases, particularly MMP-2 (gelatinase A) and MMP-9 (gelatinase B) play key roles in tumor cell invasion and metastasis due to their ability to degrade type IV collagen, a major component of the ECM (16-18). Increased 
expression of MMP-2 is associated with an increased Gleason score and aggressive behavior of prostate cancer (11). Nemeth et al reported that studies conducted in vivo and in vitro on metastasized prostate cancer to bone, revealed that MMPs play a significant role in both metastatic tumor growth and bone matrix turnover (19). MMP-2 and MMP-9 are secreted in their latent zymogenic form, 72 and $92 \mathrm{kDa}$, respectively, and these inactive pro-enzymes are cleaved by other MMPs or proteases to yield the activated forms of 68, 58 and $54 \mathrm{kDa}$ for MMP-2, and $84 \mathrm{kDa}$ for MMP-9. Proteolytic activities of MMP-2 and MMP-9 are inhibited by specific inhibitors, tissue inhibitors of metalloproteinases (TIMPs). Thus, a critical determinant of net proteolytic degradation is the balance between MMP and TIMP levels.

The serine protease u-PA, a 55-kDa serine protease consisting of two disulfide bridges linked to poypeptides, is cleaved to the active chain $(33 \mathrm{kDa})$ by various stimuli. The protease u-PA converts plasminogen to plasmin, which is capable of promoting tumor growth and angiogenesis, degrading the ECM and basement membrane and activating pro-MMPs (20). Synthetic u-PA inhibitors have been reported to inhibit metastasis of prostate and mammary carcinoma cell lines $(21,22)$.

Rath and Pauling (23) proposed that nutrients such as lysine and ascorbic acid be utilized to target plasmin-mediated connective tissue degradation as a universal approach to tumor growth and expansion. Lysine binds to plasminogen active sites and thereby blocks the activation of plasminogen into plasmin by tissue plasminogen activator (t-PA), resulting in modulation of the plasmin-induced MMP activation cascade (23). Subsequent studies confirmed this approach and resulted in identifying a novel formulation composed of lysine, ascorbic acid, proline and green tea extract and other micronutrients (NM), which has shown significant anticancer activity against a large number $(40)$ of cancer cell lines, blocking cancer growth, tissue invasion and MMP expression both in vitro and in vivo (24). In this study, we focused on the modulating effect of NM on the activities of MMP-2 and -9, TIMPs and u-PA in prostate cancer cell lines PC-3 and DU-145.

\section{Materials and methods}

Cancer cell lines and reagents. Human prostate cancer cell lines PC-3 and DU-145 and their recommended media were purchased from ATCC (Manassas, VA, USA). Penicillin, streptomycin, PMA and fetal bovine serum (FBS) were obtained from Sigma (St. Louis, MO). All other reagents used were of high purity and were obtained from Sigma, unless otherwise indicated.

Composition of the nutrient mixture. The nutrient mixture (NM) was composed of the following in the ratio indicated: vitamin $\mathrm{C}$ (as ascorbic acid and as $\mathrm{Mg}, \mathrm{Ca}$ and palmitate ascorbate), $700 \mathrm{mg}$; L-lysine, $1000 \mathrm{mg}$; L-proline, $750 \mathrm{mg}$; L-arginine, 500 mg; N-acetyl cysteine, 200 mg; standardized green tea extract [derived from green tea leaves, obtained from US Pharma Lab; the certificate of analysis indicated the following characteristics: total polyphenol $80 \%$, catechins $60 \%$, epigallocatechin gallate (EGCG) $35 \%$ and caffeine $1.0 \%$ ], $1000 \mathrm{mg}$; selenium, $30 \mu \mathrm{g}$; copper, $2 \mathrm{mg}$; manganese, $1 \mathrm{mg}$.
Cell culture. Human prostate cancer cell lines PC-3 and DU-145 were grown in MEM supplemented with 10\% FBS, penicillin (100 units $/ \mathrm{ml})$ and streptomycin $(100 \mu \mathrm{g} / \mathrm{ml})$ in 24-well tissue culture plates (Coster, Cambridge, MA). The cells were plated at a density $1 \times 10^{5}$ cells $/ \mathrm{ml}$ and grown to confluency in a humidified atmosphere at $5 \% \mathrm{CO}_{2}$ at $37^{\circ} \mathrm{C}$. Serum-supplemented media were removed and the cell monolayer was washed once with PBS and with the recommended serum-free medium. Cells were incubated with $1 \mathrm{ml}$ of media at $37^{\circ} \mathrm{C}$ in a tissue culture incubator equilibrated with $95 \%$ air and $5 \% \mathrm{CO}_{2}$. At near confluence, the cells were treated with the nutrient mixture, dissolved in media and tested at 0 , $10,50,100,500$ and $1000 \mu \mathrm{g} / \mathrm{ml}$ in triplicate at each dose. Parallel sets of cultures were treated with PMA $(100 \mathrm{ng} / \mathrm{ml})$ for induction of MMP-9. Control and PMA treatments were carried out in triplicates. The plates were then returned to the incubator. The conditioned media were collected separately, pooled, and centrifuged at $40^{\circ} \mathrm{C}$ for $10 \mathrm{~min}$ at $3000 \mathrm{rpm}$ to remove cells and cell debris. The supernatant was collected and used to assess for u-PA activity (by fibrin zymography on $10 \%$ SDS-PAGE gels containing fibrinogen and plasminogen), MMP-2 and -9 (by gelatinase zymography) and TIMPs (by reverse zymography).

Fibrin zymography. Fibrin zymography was used to analyze u-PA activity on $10 \%$ SDS-PAGE gels containing fibrinogen $(5.5 \mathrm{mg} / \mathrm{ml})$ and plasminogen $(50 \mu \mathrm{g} / \mathrm{ml})$. After electrophoresis, the gels were washed twice with $2.5 \%$ Triton $\mathrm{X}-100$ for $30 \mathrm{~min}$. The gels were then incubated overnight at $37^{\circ} \mathrm{C}$ with $0.1 \%$ glycine buffer $\mathrm{pH} 7.5$ and then stained with $0.5 \%$ Coomassie Brilliant Blue R250 and destained. Electrophoresis of u-PA was conducted for comparison. Fibrin zymograms were scanned using CanoScan 9950F Canon Scanner.

Gelatinase zymography. Gelatinase zymography was performed in $10 \%$ Novex Pre-Cast SDS Polyacrylamide Gel (Invitrogen Corp.) in the presence of $0.1 \%$ gelatin under nonreducing conditions. Culture media $(20 \mu \mathrm{l})$ were mixed with sample buffer and loaded for SDS-PAGE with Tris glycine SDS buffer as suggested by the manufacturer (Novex). Samples were not boiled before electrophoresis. Following electrophoresis the gels were washed twice in $2.5 \%$ Triton $\mathrm{X}-100$ for $30 \mathrm{~min}$ at room temperature to remove SDS. The gels were then incubated at $37^{\circ} \mathrm{C}$ overnight in substrate buffer containing $50 \mathrm{mM}$ Tris- $\mathrm{HCl}$ and $10 \mathrm{mM} \mathrm{CaCl}_{2}$ at $\mathrm{pH} 8.0$ and stained with $0.5 \%$ Coomassie Brilliant Blue R250 in 50\% methanol and $10 \%$ glacial acetic acid for $30 \mathrm{~min}$ and destained. Upon renaturation of the enzyme, the gelatinases digest the gelatin in the gel and give clear bands against an intensely stained background. Protein standards were run concurrently and approximate molecular weights were determined by plotting the relative mobilities of known proteins.

Reverse zymography. TIMPs were analyzed by reverse zymography on $15 \%$ SDS gels containing serum-free conditioned medium from cells. After electrophoresis, the gels were washed twice with $2.5 \%$ Triton-X for $30 \mathrm{~min}$ at room temperature to remove SDS. The gels were then incubated at $37^{\circ} \mathrm{C}$ overnight in $50 \mathrm{mM}$ Tris- $\mathrm{HCl}$ and $10 \mathrm{mM} \mathrm{CaCl}_{2}$ at $\mathrm{pH} 7.6$ and stained with $0.5 \%$ Coomassie Brilliant Blue R250, destained and scanned. 
A

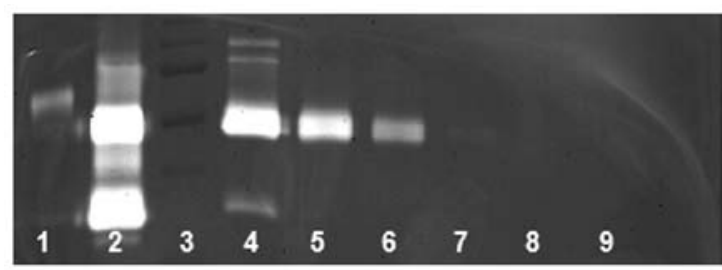

Subunit 1

Subunit 2

C

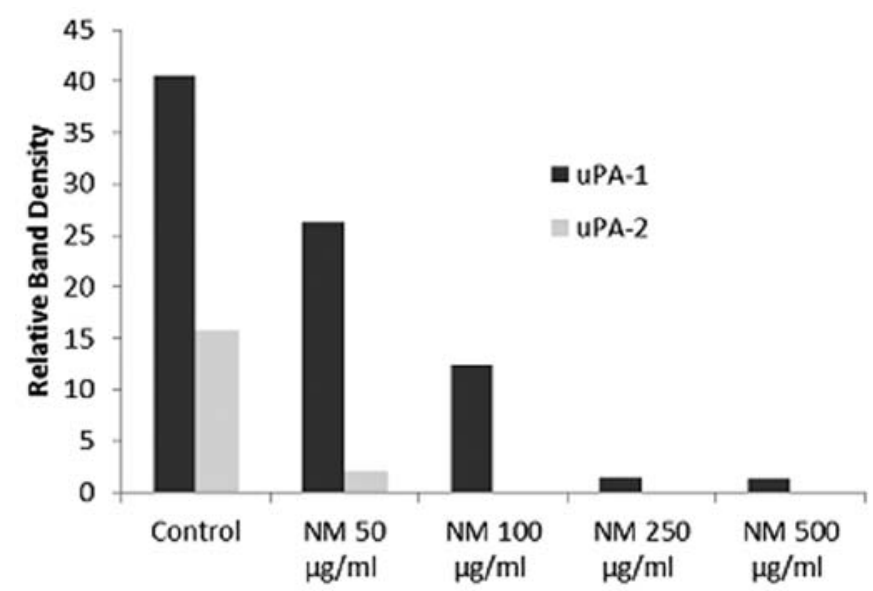

B

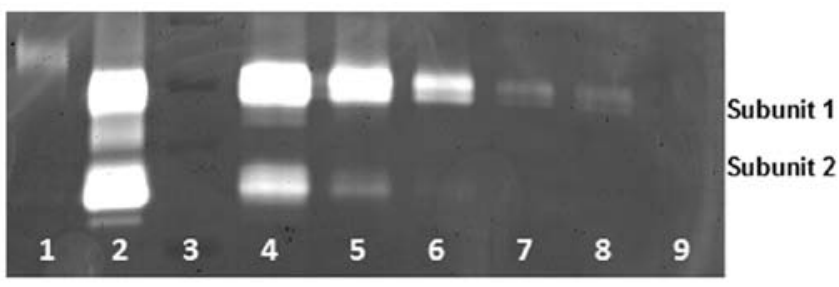

D

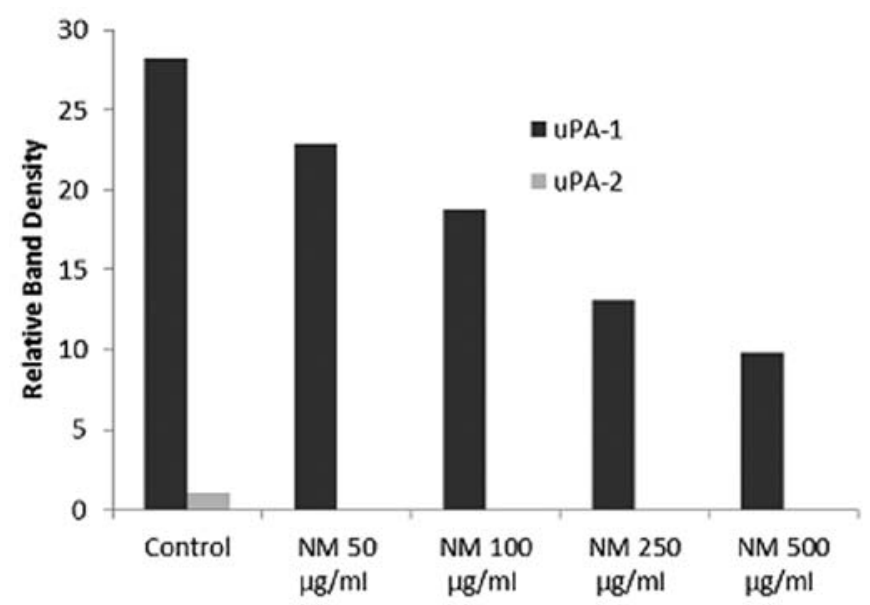

Figure 1. Effect of NM on prostate cancer cell line PC-3 and DU-145 u-PA expression. Fibrin zymograms of PC-3 u-PA expression (A) and DU-145 u-PA expression (B). Lane 1, t-PA; 2, u-PA; 3, markers; 4, control; 5-9, NM 50, 100, 250, 500, $1000 \mu \mathrm{g} / \mathrm{ml}$. Densitometric analyses of PC-3 u-PA expression (C) and DU-145 u-PA expression (D).

Scanning of gelatinase and fibrin zymograms. Gelatinase and fibrin zymograms were scanned using CanoScan 9950F Canon scanner at 300 dpi. The intensity of the bands was evaluated using the pixel-based densitometer program Un-Scan-It, version 5.1, 32-bit, by Silk Scientific Corp. (Orem, UT, USA), at a resolution of 1 scanner unit (1/100 of an inch for an image that was scanned at $100 \mathrm{dpi}$ ). The pixel densitometer calculates the optical density of each pixel (values 0-255) using the darkly stained background of the gel as a pixel value of 0 . A logarithmic optical density scale was used since the optical density of films and gels is logarithmically proportional to the concentration. The pixel densitometer sums the optical density of each pixel to determine the band density. In all graphs, band densities were reported as percentages of the sums of all pixels in a given lane (treatment) of a gel.

Statistical analysis. Pearson's correlation coefficient was determined between the mean MMP-2, u-PA and TIMP expression of prostate cancer cell line PC-3 and u-PA and TIMP expression of cell line DU-145 using MedCalc Software (Mariakerke, Belgium).

\section{Results}

Effect of NM on u-PA activity in prostate cancer cell lines $P C-3$ and DU-145. Both prostate cancer cell lines PC-3 and DU-145 expressed uPA, showing two bands corresponding to molecular weights 35 and $33 \mathrm{kDa}$. Prostate cancer cell line
PC-3 secretion of u-PA subunit 1 was decreased by $65 \%$ (linear trend: $\left.\mathrm{R}^{2}=0.994\right)$ at $\mathrm{NM} 500 \mu \mathrm{g} / \mathrm{ml}$ and subunit 2 by $100 \%$ at NM $50 \mu \mathrm{g} / \mathrm{ml}$. Prostate cancer cell line DU-145 secretion of u-PA subunit 1 was decreased by $97 \%$ (linear trend: $\mathrm{R}^{2}=0.930$ ) at NM $500 \mu \mathrm{g} / \mathrm{ml}$ and subunit 2 by $100 \%$ at NM $100 \mu \mathrm{g} / \mathrm{ml}$. Fibrin zymograms of PC-3 and DU-145 u-PA expression are shown in Fig. 1A and B, respectively. Densitometry analyses of u-PA expression in PC-3 and DU-145 are shown in Fig. 1C and $\mathrm{D}$, respectively.

Effect of NM on MMP-2 and MMP-9 expression by prostate cancer cell lines $P C-3$ and $D U-145$. Gelatinase zymography demonstrated secretion of both MMP-2 and MMP-9 by untreated prostate cancer cell line PC-3. MMP-9 secretion was enhanced with PMA (100 ng/ml) treatment (Fig. 2). NM inhibited both MMP-2 and MMP-9 secretion of normal PC-3 cells in a dose-dependent manner, with $92 \%$ inhibition of MMP-2 at $100 \mu \mathrm{g} / \mathrm{ml}$ and $100 \%$ block at $500 \mu \mathrm{g} / \mathrm{ml} \mathrm{NM}$ (linear trend: $\mathrm{R}^{2}=0.883$ ) compared to the control; MMP-9 secretion was inhibited by NM by $76 \%$ at $100 \mu \mathrm{g} / \mathrm{ml}$ and completely blocked at $500 \mu \mathrm{g} / \mathrm{ml} \mathrm{NM}$ (linear trend: $\mathrm{R}^{2}=0.7154$ ). PMA-treated PC-3 cell MMP-2 secretion was completely blocked at NM $100 \mu \mathrm{g} /$ $\mathrm{ml}$ (linear trend: $\mathrm{R}^{2}=0.883$ ) and MMP-9 secretion was inhibited by $61 \%$ at $100 \mu \mathrm{g} / \mathrm{ml}$ and completely blocked at $500 \mu \mathrm{g} / \mathrm{ml}$ NM $\left(\mathrm{R}^{2}=0.750\right)$. Notably, DU-145 did not exhibit MMP bands. Gelatinase zymograms of PC-3 MMP-2 and -9 expression are shown in Fig. 2A and B, respectively. Densitometric analyses of PC-3 MMP expression are shown in Fig. 2C and D, respectively. 
A

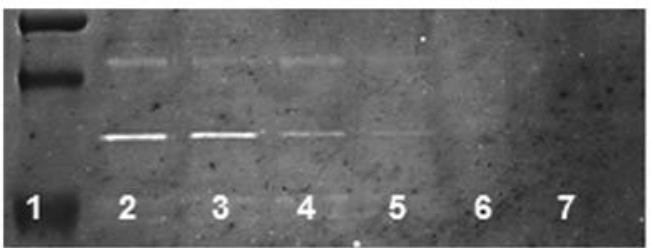

C

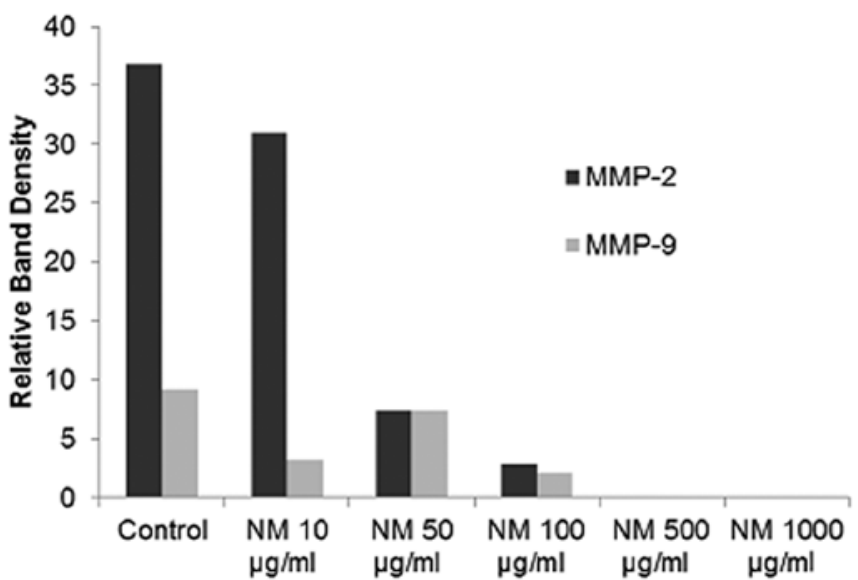

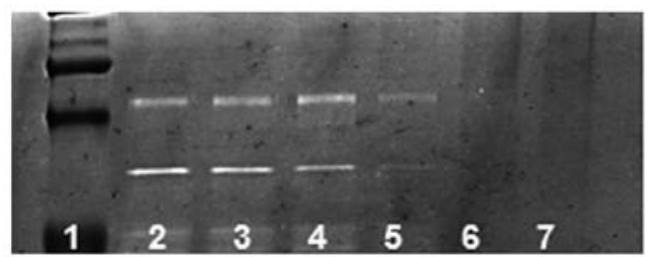

MMP-9

MMP-2

D

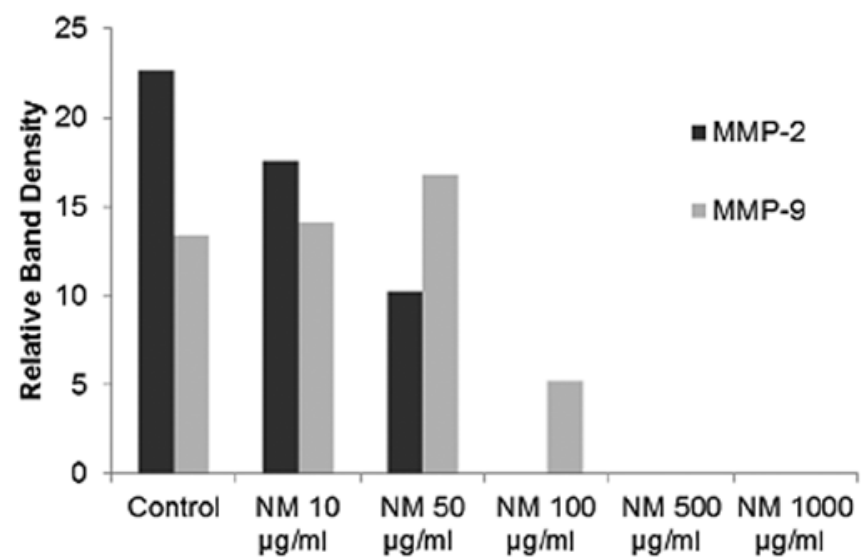

Figure 2. Effects of NM on prostate cancer cell line PC-3 MMP-2 and -9 expression. Gelatinase zymograms of normal PC-3 cell MMP-2 and -9 secretion (A) and PMA-treated PC-3 cell MMP-2 and -9 secretion (B). Lane 1, markers; 2, control; 3-7, NM 50, 100, 250, 500, $1000 \mu \mathrm{g} / \mathrm{ml}$. Densitometric analyses of normal PC-3 MMP-2 and -9 secretion (C) and PMA-treated PC-3 MMP-2 and -9 secretion (D).

A

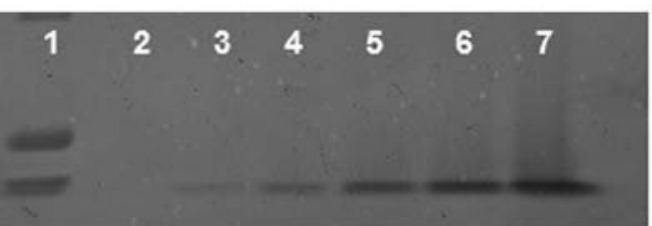

TIMP-2

C

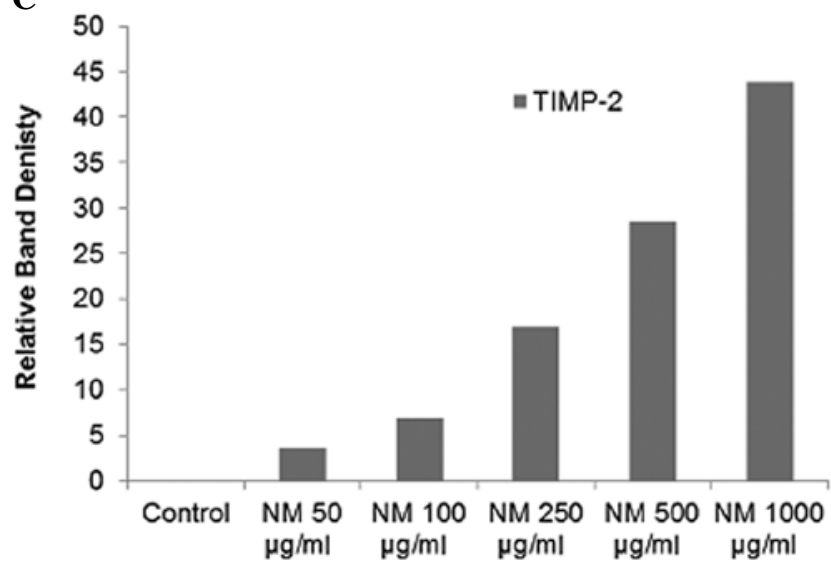

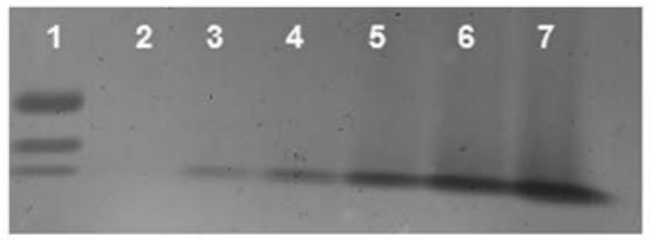

TIMP-2

D

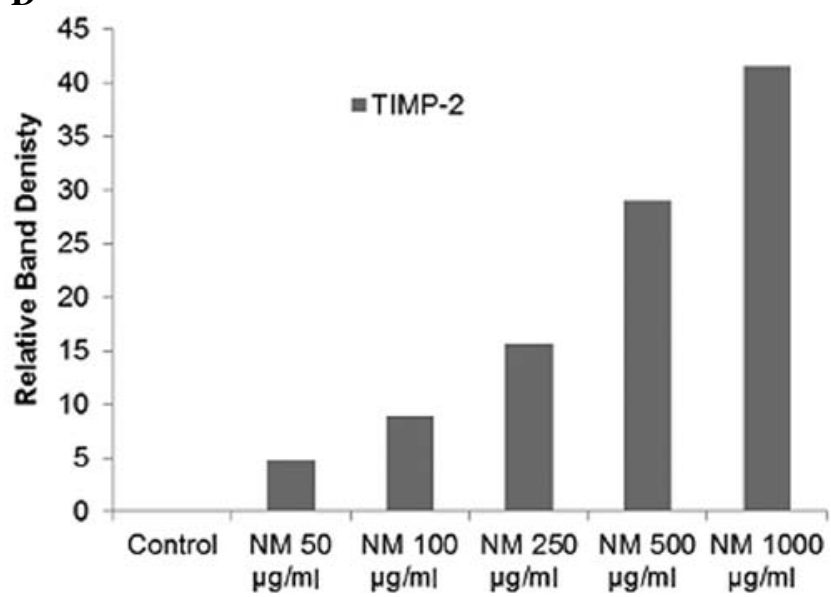

Figure 3. Effect of NM on prostate cancer cell line PC-3 and DU-145 TIMP expression. Gelatinase zymograms of PC-3 TIMP-2 expression (A) and DU-145 TIMP-2 expression (B). Lane 1, markers; 2, control; 3-7, NM 50, 100, 250, 500, $1000 \mu \mathrm{g} / \mathrm{ml}$. Densitometric analyses of PC-3 TIMP-2 expression (C) and DU-145 TIMP-2 expression (D).

Effect of NM on TIMP activity in prostate cancer PC-3 and $D U-145$ cell lines. Activity of TIMPs was up-regulated by NM in both cancer cell lines PC-3 (Fig. 3A and C) and DU-145 (Fig. 3B and D) in a dose-dependent manner. NM-treated
PC-3 cancer cells showed slight TIMP-2 activity at $50 \mu \mathrm{g} / \mathrm{ml}$ $\mathrm{NM}$, which increased to $457 \%$ over the minimal activity at $250 \mu \mathrm{g} / \mathrm{ml}$, and achieved a maximum increase of $1186 \%$ over the minimal activity at $1000 \mu \mathrm{g} / \mathrm{ml} \mathrm{NM}$ (linear trend: $\mathrm{R}^{2}=0.927$ ). 
A

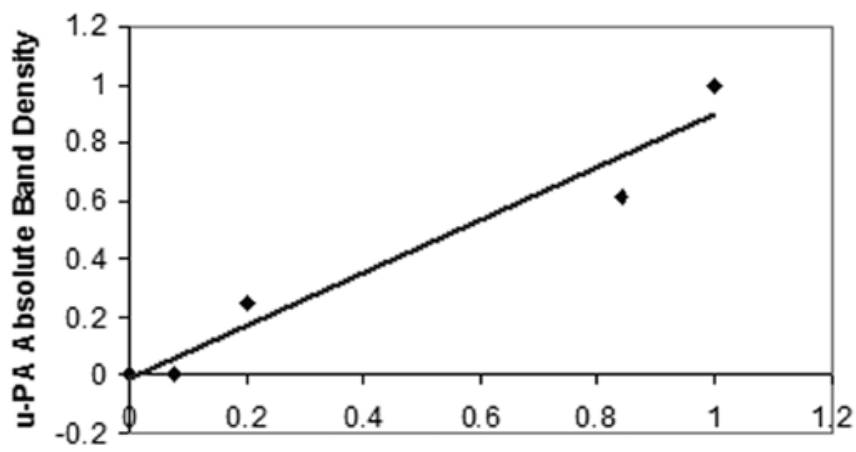

MMP-2 Absolute Band Density

C

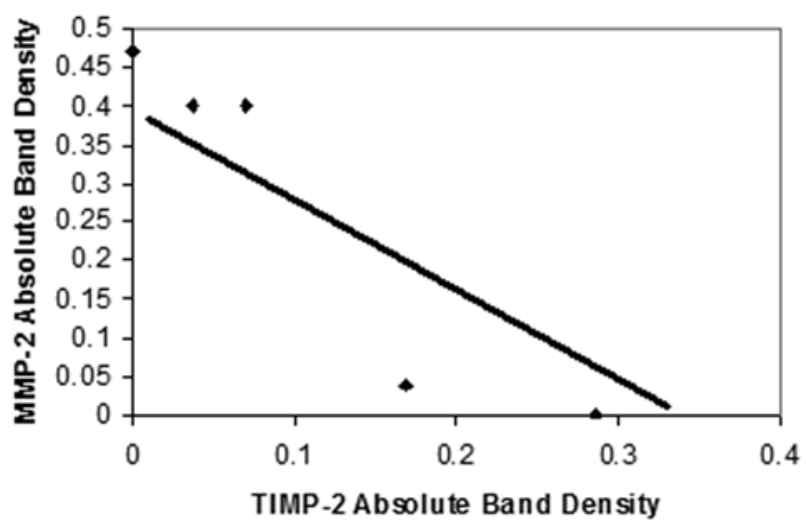

B

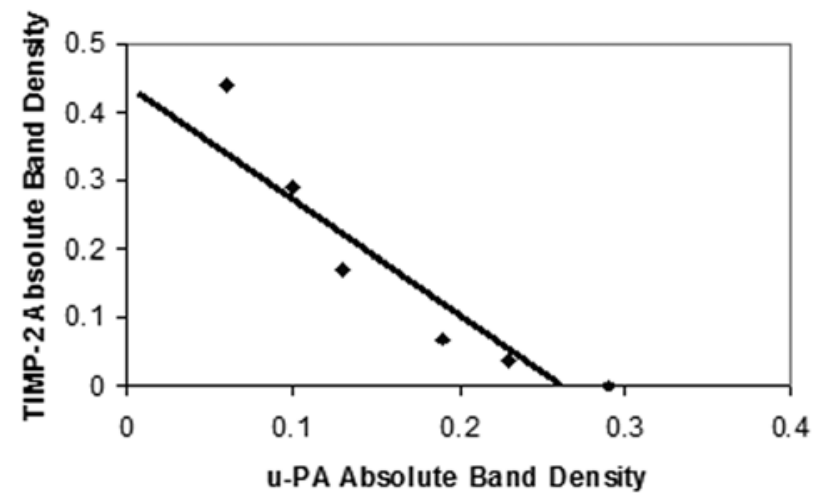

D

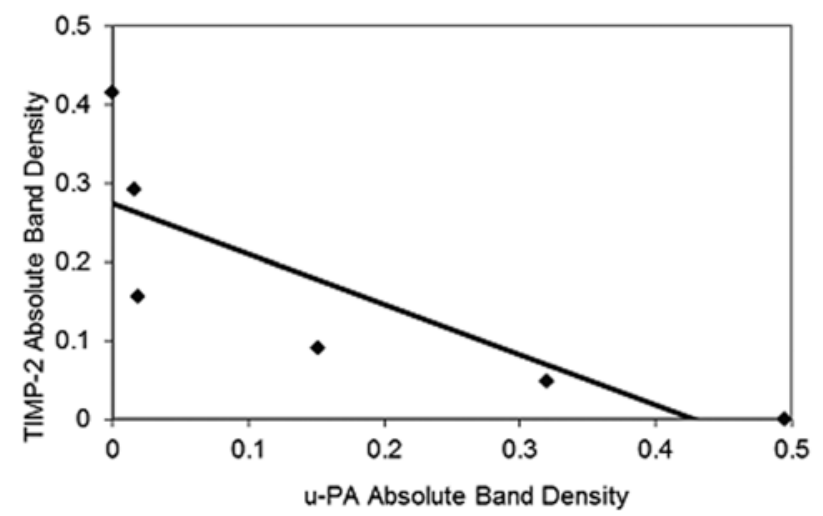

Figure 4. (A) Correlation between the effects of NM on prostate cancer PC-3 u-PA and MMP-2 expression. (B) Correlation between the effects of NM on prostate cancer PC-3 TIMP-2 and u-PA expression. (C) Correlation between the effects of NM on prostate cancer PC-3 MMP-2 and TIMP-2 expression. (D) Correlation between the effects of NM on prostate cancer DU-145 u-PA and TIMP-2 expression.

NM-treated DU-145 cancer cells showed slight TIMP-2 activity at $50 \mu \mathrm{g} / \mathrm{ml} \mathrm{NM}$, which increased to $332 \%$ over the minimal activity at $250 \mu \mathrm{g} / \mathrm{ml}$, and achieved a maximum increase of $885 \%$ over the minimal activity at $1000 \mu \mathrm{g} / \mathrm{ml} \mathrm{NM}$ (linear trend: $\mathrm{R}^{2}=0.941$ ).

Correlation between PC-3 u-PA, TIMP-2 and MMP expression. Analysis revealed a positive correlation between prostate cancer cell line PC-3 u-PA and MMP expression, as shown in Fig. 4A, with a correlation coefficient $r=0.977$. A negative correlation (correlation coefficient $r=-0.939$ ) was found between the expression of PC-3 u-PA and TIMP-2 (Fig. 4B). Prostate cancer PC-3 showed a negative correlation (correlation coefficient $r=-0.781$ ) between expression of MMPs and TIMP-2 (Fig. 4C).

Correlation between DU-145 TIMP-2 and u-PA expression. A negative correlation (correlation coefficient $\mathrm{r}=-0.815$ ) was found between DU-145 expression of TIMP-2 and u-PA (Fig. 4D).

\section{Discussion}

Critical events in tumor cell invasion include cell attachment, degradation of the ECM and migration through the disrupted matrix. The two families of proteases, matrix metalloprotein- ases and urokinase plasminogen activators play key roles in tumor cell invasion. Experimental studies have demonstrated the role of urokinase plasminogen, especially cell surface u-PA, as an initiator of ECM proteolysis and associated tumor cell invasion (25). The protease u-PA converts plasminogen to plasmin, which is capable of promoting tumor growth and angiogenesis, degrading the ECM and basement membrane and activating pro-MMPs (20). A positive correlation has been found between levels of u-PA in prostate cancer and its progression after radical prostatectomy and metastasis (12). In vivo experimental studies document increased skeletal metastasis with prostate cancer cell urokinase overproduction (13). Matrix metalloproteinases, particularly MMP-2 and MMP-9 play pivotal roles in tumor cell invasion and metastasis due to their ability to degrade type IV collagen, a major component of the ECM. Overproduction of MMPs, especially MMP-2 and -9 have been associated with a more aggressive behavior of prostate cancer $(11,19)$.

Our study demonstrated that the specific mixture of nutrients tested significantly inhibited prostate cancer u-PA and MMP secretion. Furthermore, the NM demonstrated dosedependent increase in TIMP-2 secretion by prostate cancer cells. As expected, a significant positive correlation was found between the secretion of u-PA and MMPs by NM-treated prostate cancer cells. Furthermore, a significant negative 
correlation was found between u-PA and TIMP-2 secretion and between MMP and TIMP-2 secretion by prostate cancer cells. A previous in vivo study of the effects of NM on prostate cancer supports these results in that it demonstrated significant inhibition of PC-3 xenograft tumor growth in nude mice and inhibition of MMP-9 and VEGF secretion and mitosis in the tissue of nutrient-supplemented mice (26).

In contrast to the associated toxicity and limited efficacy of standard cancer chemotherapy and radiation therapy, extensive research has documented the efficacy and safety of dietary and botanical natural compounds in cancer prevention (27). The nutrient mixture was formulated by selecting nutrients that act on critical physiological targets in cancer progression and metastasis, as documented in both clinical and experimental studies. Combining these micronutrients expands metabolic targets, maximizing biological impact with lower doses of components. For example, a previous study of the comparative effects of NM, green tea extract and EGCG on inhibition of MMP-2 and MMP-9 secretion of different cancer cell lines with varying MMP secretion patterns, documented the superior potency of NM over GTE and EGCG at equivalent doses (28). These results can be understood from the more comprehensive treatment offered by the combination of nutrients in NM over individual components of NM since MMP-2 and MMP-9 are mediated by differential pathways.

Optimal ECM structure is dependent upon adequate supplies of ascorbic acid and the amino acids lysine and proline to ensure proper synthesis and hydroxylation of collagen fibers. In addition, lysine contributes to ECM stability as a natural inhibitor of plasmin-induced proteolysis $(23,29)$. Manganese and copper are also essential for collagen formation. There is considerable documentation of the potency of green tea extract in modulating cancer cell growth, metastasis, angiogenesis, and other aspects of cancer progression (30-36). N-acetyl cysteine and selenium have been reported to inhibit MMP-9 and invasive activities of tumor cells, as well as migration of endothelial cells through ECM (37-39). Ascorbic acid demonstrates cytotoxic and antimetastatic actions on malignant cell lines (40-44) and cancer patients have been shown to have low levels of ascorbic acid $(45,46)$. Low levels of arginine, a precursor of nitric oxide (NO), can limit the production of NO, which has been shown to predominantly act as an inducer of apoptosis (47).

In conclusion, the NM demonstrated potent anticancer activity by targeting primary mechanisms responsible for the aggressive spread of prostate cancer. In this in vitro study, the NM significantly inhibited prostate cancer cell line PC-3 and DU-145 secretion of u-PA and MMP-2 and -9 and increased their secretion of TIMPs, suggesting its potential in modulating prostate cancer invasion and metastasis. Furthermore, use of the nutrient mixture would not pose any toxic effect clinically, particularly at the relevant doses, as in vivo safety studies demonstrate. An in vivo toxicology study showed that NM had no adverse effects on vital organs (heart, liver and kidney) or on the associated functional serum enzymes (48).

\section{Acknowledgements}

Mr. Monterrey provided assistance in scanning the gels. The research study was funded by the Dr Rath Health Foundation (Plantation, FL, USA) a non-profit organization.

\section{References}

1. Jemal A, Seigal R, Xu J and Ward E: Cancer statistics, 2010. CA cancer J Clin 60: 277-300, 2010.

2. Fidler IJ: Molecular biology of cancer: invasion and metastasis In: Cancer: Principles and Practice of Oncology. 5th edition. De Vita VT, Hellman S and Rosenberg SA (eds). Lippincott-Raven, Philadelphia, pp135-152, 1997.

3. Egeblad M and Werb Z: New functions for the matrix metalloproteinases in cancer progression. Nat Rev Cancer 2: 161-174, 2002.

4. Folkman J: Role of angiogenesis in tumor growth and metastasis. Semin Oncol 29 (Suppl 16): S15-S18, 2002.

5. Chambers AF and Matrisian LM: Changing views on the role of matrix metalloproteinases in metastasis. J Natl Cancer Inst 89: 1260-1270, 1997.

6. Kleiner DL and Stetler-Stevenson WG: Matrix metalloproteinases and metastasis. Cancer Chemother Pharmacol 43 (Suppl): S42-S51, 1999.

7. Nelson AR, Fingleton B, Rothenberg ML and Matrisian LM: Matrix metalloproteinases: biologic activity and clinical implications. J Clin Oncol 18: 1135-1149, 2000.

8. Bérubé M, Deschambeault A,Boucher M, Germain L, Petitclerc E and Guérin SL: MMP-2 expression in uveal melanoma: differential activation status dictated by the cellular environment. Mol Vis 11: 1101-1111, 2005.

9. Garzetti G, Ciavattini A, Lucarini G, Goteri G, De Nicolis M, Garbisa S, Masiero L, Romanini C and Graziella B: Tissue and serum metalloproteinase (MMP-2) expression in advanced ovarian serous cystadenocarcinomas: clinical and prognostic implications. Anticancer Res 15: 2799-2804, 1995.

10. Gohji K, Fujomoto N, Hara I, Fujii A, Gotoh A, Okada H, Arakawa S, Kitazawa S, Miyake H, Kamidono S and Nakijima M: Serum matrix metalloproteinase-2 and its density in men with prostate cancer as a new predictor of disease extension. Int $\mathbf{J}$ Cancer 79: 96-101, 1998

11. Lokeshwar BL: MMP inhibition in prostate cancer. Ann NY Acad Sci 878: 271-289, 1999.

12. Shariat SF, Roehrborn CG, McConnell JD, Park S, Alam N, Wheeler TM and Slawin KM: Association of the circulating levels of the urokinase system of plasminogen activation with the presence of prostate cancer and invasion, progression and metastasis. J Clin Onc 25: 349-355, 2007.

13. Achbarou A, Laiser S, Tremblay G, Ste-Marie LG, Brodt P, Goltzman D and Rabbani SA: Urokinase overproduction results in increased skeletal metastasis by prostate cancer cells in vivo. Cancer Res 54: 2372-2377, 1994.

14. Yurchenko PD and Schitny JC: Molecular architecture of basement membranes. FASEB J 4: 1577-1590, 1990.

15. Barsky SH, Siegel GP, Jannotta F and Liotta LA: Loss of basement membrane components by invasive tumors but not by their benign counterparts. Lab Invest 49: 140-147, 1983.

16. Liotta LA, Tryggvason K, Garbisa A, Hart I, Foltz CM and Shafie S: Metastatic potential correlates with enzymatic degradation of basement membrane collagen. Nature 284: 67-68, 1980.

17. Stetler-Stevenson WG: The role of matrix metalloproteinases in tumor invasion, metastasis and angiogenesis. Surg Oncol Clin N Am 10: 383-392, 2001.

18. Stetler-Stevenson WG: Type IV collagenases in tumor invasion and metastasis. Cancer Metastasis Rev 9: 289-303, 1990.

19. Nemeth JA, Yousif R, Herzog M, Che M, Upadhyay J, Shekarriz B, Bhagat S, Mullins C, Fridman R and Cher ML: Matrix metalloproteinase activity, bone matrix turnover, and tumor cell proliferation in prostate cancer bone metastasis. J Natl Cancer Inst 94: 17-25, 2002.

20. Dano K, Andreasen PA, Grondahl-Hansen J, Kristensen P, Nielsen LS and Skriver L: Plasminogen activators, tissue degradation and cancer. Adv Cancer Res 44: 139-266, 1985.

21. Evans CP,Elfman F,Parangi S, Conn M,Cunha G and Shuman MA: Inhibition of prostate cancer neovascularization and growth by urokinase-plasminogen activator receptor blockade. Cancer Res 57: 3594-3599, 1997.

22. Alonso DF, Farias EF, Ladeda V, Davel L, Puricelli L and Val de Kier Joffé E: Effects of synthetic urokinase on local invasion and metastasis in a murine mammary tumor model. Breast Cancer Res Treat 40: 209-223, 1996.

23. Rath M and Pauling L: Plasmin-induced proteolysis and the role of apoprotein(a), lysine and synthetic analogs. Orthomol Med 7: 17-23, 1992. 
24. Niedzwiecki A, Roomi MW, Kalinovsky $\mathrm{T}$ and Rath $\mathrm{M}$ : Micronutrient synergy - a new tool in effective control of metastasis and other key mechanisms of cancer. Cancer Metastasis Rev 29: 529-543, 2010.

25. Andreasen PA, Kjøller L, Christensen L and Duffy MJ: The urokinase-type plasminogen activator system in cancer metastasis: a review. Int J Cancer 72: 1-22, 1997.

26. Roomi MW, Ivanov V, Kalinovsky T, Niedzwiecki A and Rath M: In vivo antitumor effect of ascorbic acid, lysine, proline and green tea extract on human prostate cancer PC-3 xenografts in nude mice: evaluation of tumor growth and immunohistochemistry. In Vivo 19: 179-184, 2005.

27. Amin ARMR, Kucek O, Khuri FR and Shin DM: Perspectives for cancer prevention with natural compounds. J Clin Oncol 27: 2712-2725, 2009.

28. Roomi MW, Monterrey JC, Kalinovsky T, Rath M and Niedzwiecki A: Comparative effects of EGCG, green tea and a nutrient mixture on the patterns of MMP-2 and MMP-9 expression in cancer cell lines. Oncol Rep 24: 747-757, 2010.

29. Sun Z, Chen YH, Wang P, Zhang J, Gurewich V, Zhang $P$ and Liu JN: The blockage of high-affinity lysine binding sites of plasminogen by EACA significantly inhibits prourokinase-induced plasminogen activation. Biochem Biophys Acta 1596: 182-192, 2002.

30. Kemberling JK, Hampton JA, Keck RW, Gomez MA and Selman SH: Inhibition of bladder tumor growth by the green tea derivative epigallocatechin-3-gallate. J Urol 170: 773-776, 2003.

31. Sato D and Matsushima M: Preventive effects of urinary bladder tumors induced by N-butyl-N-(4-hydroxybutyl)-nitrosamine in rat by green tea leaves. Int J Urol 10: 160-166, 2003

32. Valcic S, Timmermann BN, Alberts DS, Wachter GA, Krutzsch M, Wymer J and Guillen JM: Inhibitory effect of six green tea catechins and caffeine on the growth of four selected human tumor cell lines. Anticancer Drugs 7: 461-468, 1996.

33. Mukhtar H and Ahmed N: Tea polyphenols: prevention of cancer and optimizing health. Am J Clin Nutr 71: S1698-S1702, 2000.

34. Yang GY, Liao J, Kim K, Yurtow EJ and Yang CS: Inhibition of growth and induction of apoptosis in human cancer cell lines by tea polyphenols. Carcinogenesis 19: 611-616, 1998.

35. Taniguchi S, Fujiki H, Kobayashi H, Go H, Miyado K, Sadano H and Shimikawa R: Effect of (-) epigallocatechin gallate, the main constituent of green tea, on lung metastasis with mouse B16 melanoma cell lines. Cancer Lett 65: 51-54, 1992.

36. Hara Y: Green tea: Health Benefits and Applications. Marcel Dekker, New York, Basel, 2001.
37. Kawakami S, Kageyama Y, Fujii Y, Kihara K and Oshima H: Inhibitory effects of N-acetyl cysteine on invasion and MMP 9 production of T24 human bladder cancer cells. Anticancer Res 21: 213-219, 2001.

38. Morini M, Cai T, Aluigi MG, Noonan DM, Masiello L, De Floro S, D'Agostinin F, Albini A and Fassima G: The role of the thiol $\mathrm{N}$-acetyl cysteine in the prevention of tumor invasion and angiogenesis. Int J Biol Markers 14: 268-271, 1999.

39. Yoon SO, Kim MM and Chung AS: Inhibitory effects of selenite on invasion of HT 1080 tumor cells. J Biol Chem 276: 20085-20092, 2001.

40. Naidu KA, Karl RC and Coppola D: Antiproliferative and proapoptotic effect of ascorbyl stearate in human pancreatic cancer cells: association with decreased expression of insulinlike growth factor 1 receptor. Dig Dis Sci 48: 230-237, 2003.

41. Anthony HM and Schorah CJ: Severe hypovitaminosis C in lungcancer patients: The utilization of vitamin $\mathrm{C}$ in surgical repair and lymphocyte-related host resistance. Br J Cancer 46: 354-367, 1982.

42. Maramag C, Menon M, Balaji KC, Reddy PG and Laxmanan S: Effect of vitamin $C$ on prostate cancer cells in vitro: effect on cell number, viability and DNA synthesis. Prostate 32: 188-195, 1997.

43. Koh WS, Lee SJ, Lee H, Park C, Park MH, Kim WS, Yoon SS, Park K, Hong SI, Chung MH and Park CH: Differential effects and transport kinetics of ascorbate derivatives in leukemic cell lines. Anticancer Res 8: 2487-2493, 1998.

44. Chen Q, Espey MG, Krishna MC, Mitchell JB, Corpe CP, Buettner GR, Shacter E and Levine M: Pharmacologic ascorbic acid concentrations selectively kill cancer cells: Action as a pro-drug to deliver hydrogen peroxide to tissues. Proc Natl Acad Sci USA 102: 13604-13609, 2005.

45. Nunez C, Ortiz de Apodaca Y and Ruiz A: Ascorbic acid in the plasma and blood cells of women with breast cancer. The effect of consumption of food with an elevated content of this vitamin. Nutr Hosp 10: 368-372, 1995.

46. Kurbacher CM, Wagner U, Kolster B, Andreotti PE, Krebs D and Bruckner HW: Ascorbic acid (vitamin C) improves the antineoplastic activity of doxorubicin, cisplatin and paclitaxel in human breast carcinoma cells in vitro. Cancer Lett 103: 183-189, 1996.

47. Cooke JP and Dzau VJ: Nitric oxide synthase: Role in the genesis of vascular disease. Annu Rev Med 48: 489-509, 1997.

48. Roomi MW, Ivanov V, Netke SP, Niedzwiecki A and Rath M: Serum markers of the liver, heart, and kidney and lipid profile and histopathology in ODS rats treated with nutrient synergy. J Am Coll Nutr 22: abs. 86, 2003. 